\title{
Private research and public benefit: The private seed industry for sorghum and pearl millet in India
}

\author{
Carl E. Pray and Sharmila Ribeiro \\ Rutgers Universily, New Brunswick, NJ 08903, USA \\ Rolf A.E. Mueller and P. Parthasarathy Rao \\ national Crops Research Institute for the Semi-Arid Tropics, Patancheru, Andhra Prodesh 502 324, India
}

Final version received November 1990

\begin{abstract}
In contrast to conventional wisdom, private firms are spending substantial amounts of moncy on research to develop new cultivars for small-farmer, subsistence agriculture. Indian firms spend almost as much as the government on breeding pearl millet and sorghum. The hybrids developed by firms are becoming popular with farmers: about 900,000 ha were planied with private pearl millet and sorghum hybrids in 1987. The higher yields of private hybrids increased grain output by at least 200,000 t. Although prices for seed of private hybrids are higher than seed of cultivars developed by government rescarch, most of the benefits from private breeding research accrue to farmers and consumers.
\end{abstract}

\section{Introduction}

Commercial seed companies are widely believed to have little interest in investing in crop breeding research to produce improved cultivars for small, semi-subsistence farmers in rain-led areas of developing countries. The lack of interest posedly is founded in the difficulty of ap-

- The research for this paper was primarily financed by USAID/New Delhi. We also received support from ICRISAT. We would like to thank the scientists of the AICSIP. AICPMIP, IARI, officials of the Ministry of Agriculture. NSC, SSC, and executives of private seed companies, for their cooperation. We also appreciate the comments of John Wiscombe. Tom Walker, and Wayne Freeman on carlier drafts of this paper. The opinions expressed in the paper are those of the authors and do not represent the opinions of USAID or ICRISAT.

Research Policy 20 (1991) 315-324

Norih-Holland propriating returns to research from varieties which can be regrown by farmers, and the lack of market demand for hybrids which could otherwise assure the appropriation of returns to research through recurrent seed sales. Furthermore, some skeptics are convinced that private enterprise would provide improved seed only at prices that left little or no benefits from research for growers battling high risks and poverty. The alleged absence of interest by private enterprise and the threat of complete appropriation of research benefits by private investors are some of the arguments justifying the dominance of crop improvement research by public research organizations in many low-income countries and the widespread absence of policies fostering privately financed crops research.

Sorghum and pearl millet are staple cereals for poor people in some of the poorest regions of India. The crops rank third and fourth, after wheat and rice, in area planted, and third and fifth in India's lood grain production. The drought-hardy coarse ccreals are grown mainly by small farmers on rain-fed dryland and only about 5 percent of their area is irrigated. Belying common belief, a vigorous private seed industry has evolved in India and new cultivars of sorghum and millet bred by private seed enterprises are competing well with seed bred in India's large public agricultural research sector.

How can private companies profitably conduct research on "poor peoples" crops" in competition 
with public research institutions? Can they do so only by capturing all of the social benefits from research or do growers and consumers also benefit? We report results from a survey of the private seed industry in India which allows us to estimate the size of the benefits from breeding by the private industry and their distribution among the seed enterprises, farmers, and consumers. The results encourage us to consider policies aimed at lostering of private breeding research.

2. The structure and evolution of the seed industry for sorghum and millet in India

The establishment of the National Seed Corporation (NSC) in 1963 was a significant milestone in the evolution of India's seed industry. The NSC provided foundation seed, training, and technical assistance to state governments and private companies. The activities of the NSC were supported and complemented by the Rockefeller Foundation and USAID, which assisted NSC's training pro- gram and provided seed processing equipment to private seed companies for seed processing. The next significant event occurred in 1969 when G.B. Pant Agricultural University in Ultar Pradesh established the Terai Seed Development Corporation with the assistance of the World Bank. The Corporation became the model for state seed corporations (SSCs) established in the 1970s and 1980 s in 12 states of India. At the same time, NSC also expanded its activities producing and distributing commercial seed in competition with the SSCs, and the private seed industry emerging in the 1970s.

State agricultural departments, NSC and privure firms all started producing hybrid sorghum and pearl millet seed in the mid-1960s. Private seed firms developed from farms or small vegetable seed companies. About 20 companies were stimulated by subsidies and price guarantees to develop into the primary seed source for improved hybrids of sorghum and pearl millet, as well as some other crops. Seed sales by the private sector grew from almost nothing in 1964 to 8,000 t, or 90 percent of
PUBLIC

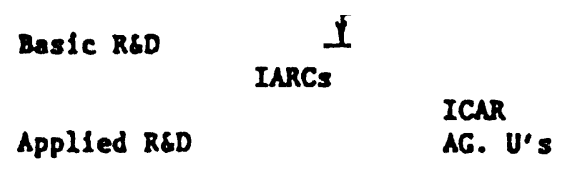

PRIVATE

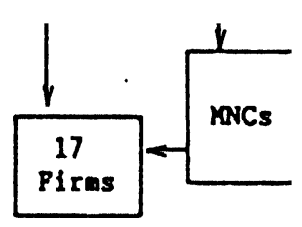

ICAR

AG. U's

17

Seed Production

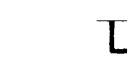

Plras

Contract
Parmers

1 $1000 \mathrm{~s}$

Distributors/ Dealers

Fif 1. Interaction between the public and private sectors. MNCs = Multinational Corporations; IARCs m International Agricultural Research Centers; ICAR - Indian Council of Agricultural Reseanch; AO. Us - State Agricultural Universities. 
tolal hybrid sorghum sales, and 9,250 t, or 70 percent of total hybrid pearl millet sales in 1975 [9]. About 60 private sced companies, 13 SSCs, the State Farm Corporation India (SFCI) and the NSC now produce commercial seed.

The current structure of the seed industry for major field crops is shown in fig. 1 where the arrows indicate the movement of germplasm and seeds between organizations. Institutes of the Indian Council of Agricultural Research (ICAR), state agricultural universities, private lirms, and (t) nternational Crops Rescarch Institute for the S. Arid Tropics (ICRISAT) conduct plant breeding research and produce breeders seed. The NSC, the SSCs, and private firms produce foundation seed. NSC and SSC distribute seed through their own seed outlets, cooperatives, and private dealers. Private dealcrs are the main sales outlet lor private seed producers.

Sorghum and millet, unlike the "green revolution" crops wheat and rice, received little research attention in India before or immediately after Independence. Research on these crops did not grow much until the early 1960s when the government funded All-India research programs for these crops. The All India Coordinated Sorghum Improvement Project (AICSIP) and its counterpart the All India Coordinated Millet Improvement Project (AICMIP) produced the first hybrids in the mid-1960s. India's own rescarch efforts were complemented and stimulated by ICRISAT after it was established in 1972.

Private companies started breeding research around 1970 but took a decade to produce commercially viable improved cultivars. The first pearl cultivar bred by a private seed company, a hybrid r. $\mathrm{MBH} 110$, was released by the Governmerl of India in 1981. Since then a number of other private hybrids have been introduced without the sanction of official release. Private seed companies were slower yet in breeding new. sorghum cultivars. The first commercially successful private sorghum hybrid was not sold until the late 1980 s.

\section{Private research and its impact}

We surveyed private seed companies to ascertain the extent and impact of private breeding research. The survey combined a mail questionnaire and direct personal interviews. Question- naires were mailed in 1987 to 51 seed companies that had received breeder seed, nurseries, or genctic material of sorghum or pearl millet from ICRISAT. The sample is not representative of the seed industry in India. It is biased toward the largest and most R\&D-intensive companies. Twenty-four companies returned usable questionnaires. The respondents include all companies that have research programs for the major field crops in India. ' Executives of 18 of the firms were also interviewed personally to collect additional information and to check the questionnaire responses.

\subsection{Privale research investment}

Private firms, as a group, make substantial investments in agricultural research. Seventeen of the firms had private breeding programs and all firms with above average seed sales also had an $R \& D$ program. The firms spent a total of Rs 19.5 million, or on average 4 percent of seed sales, on research. This compares well with the seed industry in the USA where companies spend about 3 percent of seed sales on research [2]. The firms employed 31 Ph.D. graduates and 45 with M.Sc. degrees; total experiment station area was 408 ha or 24 ha per firm with an R\&D program.

The number of firms in our sample conducting research on a particular crop is given in table 1 . The number of firms concerned with millet, sorghum, and corn breeding is evidence contradicting the belief that private firms would not be interested in breeding poor peoples' crops.

Estimated total research expenditure by the respondent firms was Rs 3.4 million for sorghum and Rs 3.7 million for millet (table 1). This is of the same order of magnitude as the research expenditure on the crops by the public sector. AICSIP spent Rs 3.3 million and the volume of the ICAR sorghum research program was about Rs 4 million in 1985; 2 AICPMIP's budget was Rs 4 million in 1985. In the same period ICRISAT,

1 The head of IARI's seed technology section, Dr. R.L. Agrawah, and Dr. Chopra, President All India Seed Growers, Merchants, and Nuerserymen's Association and Vice President, Indian Seed Association, examined by list of respondents in February 1988. They could not identify companies that were doing RAD on field crops but not included in the survey.

2 Interview with-AICSIP Coordinator, January 1988. 
Table 1

R\&D programs and expenditure by crop

\begin{tabular}{lll}
\hline & $\begin{array}{l}\text { Number of } \\
\text { companies } \\
\text { with R\&D }\end{array}$ & $\begin{array}{l}\text { R\&D ex- } \\
\text { penditure } \\
\text { by crop } \\
\text { (Rs million) }\end{array}$ \\
\hline Pearl millet & 12 & 3.7 \\
Sarghum & 10 & 3.4 \\
Sunflower & 10 & 3.5 \\
Cotton & 9 & 2.1 \\
Corn & 6 & 2.1 \\
Vegetables & 5 & 0.9 \\
Fodder & 2 & 1.0 \\
Pigeonpea & 2 & 1.0 \\
Saffower & 2 & 0.7 \\
Mustard & 1 & 0.4 \\
Sesame & 1 & 0.7 \\
Total & & 19.5 \\
\hline
\end{tabular}

- Estimated by dividing a firm's total research expenditure by the number of crops on which the firm reported doing research and adding over the firms.

Source: Survey.

which usually has higher costs than national research institutions, spent in India about Rs 13 million each for research on sorghum and pearl millet.

\subsection{Private returns 10 research}

Private seed firms invest in research in the expectation of increased seed sales, or higher margins on sales, or both. Sales of millet and sorghum hybrids bred by private companies have grown rapidly in the last three years (table 2). Private sector pearl millet hybrid seed is planted on about 660,000 ha but private sector hybrid sorghum is grown on only 258,000 ha.

The firms' seed enterprise margins are estimated in table 3. The procurement price is $t$ price paid by companies for seed grown by tract farmers. The procurement price is the maj cost of growing the seed but not the only cost. Other costs, not accounted in our calculation, are the costs of identifying and negotiating contracts with farmers, technical advice provided by the companies, the costs for inputs occasionally supplied to farmers, and the costs of supervising the crossing of inbreds. These costs and the costs of establishing and maintaining a distribution system are met out of the seed company's margin. The price spread is the difference between the retail price and the procurement price. Under the reasonable assumption that the cost elements of seed processing and distribution that are not accounted

Table 2

Private seed sales and area covered, 1985-87

\begin{tabular}{|c|c|c|c|c|c|c|}
\hline & \multicolumn{3}{|c|}{ Seed sales ( $($ ) } & \multicolumn{3}{|c|}{ Area (1000 ha) } \\
\hline & 1985 & 1986 & 1987 & 1985 & 1986 & 1987 \\
\hline & \multicolumn{6}{|c|}{ Pearl millet } \\
\hline \multicolumn{7}{|l|}{ Private companies } \\
\hline Private hybrids & 220 & 1,557 & 2,651 & S5 & 389 & 663 \\
\hline Public hybrids & 380 & 794 & 1,255 & 95 & 199 & 314 \\
\hline Public varieties & 412 & 877 & 881 & 103 & 219 & 220 \\
\hline Private total & 1.012 & 3.228 & 4,787 & 253 & 807 & 1,197 \\
\hline \multirow[t]{2}{*}{ SSC's total : : } & 10,070 & 8.870 & 9,046 & 2,518 & 2,218 & 2,262 \\
\hline & \multicolumn{6}{|c|}{ Sorghum } \\
\hline \multicolumn{7}{|l|}{ Private companies } \\
\hline Private hybrids & 257 & 847 & 2,067 & 32 & 106 & 258 \\
\hline Privale varieties & & 6 & 20 & & 1 & 3 \\
\hline Public hybrids & 1.761 & 3,480 & 5,115 & 220 & 435 & 639 \\
\hline Private total & 2,018 & 4,333 & 7,202 & 252 & 542 & 900 \\
\hline SSC's toul & 18,900 & n.a. & n.2. & 2,363 & n.a. & n.a. \\
\hline
\end{tabular}

Aress were calculated from sales, using the recommended seed rate of $4 \mathrm{~kg} \mathrm{ha}^{-1}$ for pearl millet and $8 \mathrm{~kg}_{\mathrm{g}} \mathrm{ha}^{-1}$ for sorghum. n.a. - not available.

Sources: Private sales from survey; SSC's pearl millet sales from AICPMIP 1988 reports and survey: SSC's sorghum sales from World Bank [9] 
Table 3

Seed firm margins $1987\left(\mathrm{Rs} \mathrm{kg}^{-1}\right)$

\begin{tabular}{|c|c|c|c|c|c|c|c|}
\hline & $\begin{array}{l}\text { Procu- } \\
\text { rement } \\
\text { price } \\
\text { (1) }\end{array}$ & $\begin{array}{l}\text { Process- } \\
\text { ing and } \\
\text { packing } \\
\text { cost } \\
\text { (2) }\end{array}$ & $\begin{array}{l}\text { Seed } \\
\text { company } \\
\text { margin }{ }^{b} \\
(3)\end{array}$ & $\begin{array}{l}\text { Whole- } \\
\text { sale } \\
\text { price } \\
\text { (4) }\end{array}$ & $\begin{array}{l}\text { Distri- } \\
\text { butor } \\
\text { margin } \\
\text { (5) }\end{array}$ & $\begin{array}{l}\text { Retail } \\
\text { price } \\
(6)\end{array}$ & $\begin{array}{l}\text { Price } \\
\text { spread } \\
(7)\end{array}$ \\
\hline \multicolumn{8}{|c|}{ Sorghum } \\
\hline \multicolumn{8}{|c|}{ Privale companics } \\
\hline Pvi.hybrid & 5.7 & 1.5 & 5.3 & 12.5 & 2.2 & 14.7 & 9.0 \\
\hline Pub.hybrid & 5.2 & 1.5 & 1.5 & 8.2 & 2.0 & 10.2 & 5.0 \\
\hline \multicolumn{8}{|c|}{ State seed corporations } \\
\hline Pub.hybrid & 5.8 & 1.5 & 2.0 & 9.3 & 0.8 & 10.1 & 4.3 \\
\hline Pub.var. & 2.8 & 1.5 & 0.3 & 4.6 & 0.4 & 5.0 & 2.2 \\
\hline \multicolumn{8}{|c|}{ Pearl millet } \\
\hline compa & 76 & 15 & 70 & 161 & 27 & & 18 \\
\hline Pub.hybnd & 5.8 & 1.5 & $\begin{array}{l}1.0 \\
2.1\end{array}$ & $\begin{array}{r}16.1 \\
9.4\end{array}$ & $\begin{array}{l}3.2 \\
2.5\end{array}$ & $\begin{array}{l}19.3 \\
11.9\end{array}$ & $\begin{array}{r}11.6 \\
6.1\end{array}$ \\
\hline Pub.var. & 3.9 & 1.5 & 1.2 & 6.6 & 1.8 & 8.4 & 4.5 \\
\hline \multicolumn{8}{|c|}{ State seed corporations } \\
\hline Pub.hybrid & 5.1 & 1.5 & 1.0 & 7.6 & 0.9 & 8.4 & 3.4 \\
\hline Pub.var. & 3.6 & 1.5 & 1.0 & 6.1 & 0.6 & 6.8 & 3.2 \\
\hline
\end{tabular}

- Privale company prices are weighted (by sales) average prices from the survey. Stalc seed corporation prices are averages of prices from Andhra Pradesh. Gujaral and Karnataka.

- Seed company margin - wholesale price - (processing and procurement costs).

- Distributor margin = retail price - wholesale price.

$\checkmark$ Price spread - Retall price-procurement price.

Source: Survey.

for in table 3 do not vary with the origin of the cultivars, the price spread provides an indication of the industry gross margin.

Seed company margins are considerably higher for sorghum and millet hybrids bred by private companies than they are for hybrids bred by the public sector. Distributors' margins are also higher for private hybrids than for public hybrids, but distributors' margins for private hybrids are much lower than seed company margins. This indicates that both seed companies and distributors gain 1 private hybrids, but the relative gain is higher fo the seed companies than for the distributors. The absolute and relative increase in the margins that seed companies obtain from private hybrids is a strong incentive for private crop breeding.

The order of magnitude of financial rates of return to private research investments can be assessed from the reported research expenditure and the seed company margins. Private research expenditure is estimated on the basis of current R\&D from our survey and the date on which the firms started research. The returns to research are taken as the seed company margins from private hybrids in table 3 minus the margins that companies could have achieved selling public hybrids. Assuming that benefits started to accrue in 1985 , reached their peak in 1987 and stayed at the 1987 level until 1995, the internal rate of return to private sorghum and pearl millet $R \& D$ was at least 17 percent. Since the costs of R\&D were spread across a number of companies while most of the benefits were captured by two companies, for two companies research was a very profitable investment.

\subsection{Impact on yield and production}

New cultivars may have important impact on production by having other desirable characteristics in addition to high yield. However, the impact of such characteristics, such as earliness or resistance to pests and discases, cannot be readily quantified. We therefore estimate only the increase in yicld and production due 10 yield improvement in private hybrids.

The yield increases from private hybrids were gauged using yield records from AICSIP and 
AICMIP and surveys of farmers. In two years of direct comparison in AICPMIP trials the widely adopted private pearl millet hybrid MBH 110 out-yielded public hybrid BJ 104 by about 23 percent. The yields of Pioneer hybrids were 7 and 10 percent higher than yields of $\mathrm{MBH} 110$. Hybrids sold recently by Pioneer and Nath yield at least as much as MBH 110. These results were stipported by our survey of farmers in Maharashtra and Gujarat [8]. Private hybrids of sorghum outyielded the public hybrid $\mathrm{CSH} 9$ in eight out of ten cases. In Maharashtra, a major sorghum growing state, CSH 9 is being replaced by MSH 51 which was not in the AICSIP trials. Farmers report that it out-yields CSH 9 by 14 percent to 20 percent in their fields [8].

We estimate the annual production increases from private hybrids to be about 152,000 t for pearl millet and $58,000 \mathrm{t}$ of sorghum. Underlying the estimates are the assumptions: (i) replacement of public millet hybrids yielding $1000 \mathrm{~kg} \mathrm{ha}^{-1}$ by private hybrids with 23 percent higher average yields, and (ii) replacement of public by private sorghum hybrids leads to a 15 percent increase over the average yield of $1500 \mathrm{~kg} \mathrm{ha}^{-1}$ of public sorghum hybrids.

\subsection{Distribution of benefits from research}

Innovating firms of an agricultural input supply industry cannot capture all of the benefits from
R\&D. Some will accrue to farmers and consumers [6]. The benefits from private hybrids for individual farmers whose production is small in comparison to total production is the value of the ad. ditional production net of changes in the costs of production. The main difference in the monetary costs of producing private and public hybrids is the costs of seed. The price difference between public and private sorghum hybrid seed is Rs 4.50 $\mathrm{kg}^{-1}$ and the difference is $\mathrm{Rs} 7.40 \mathrm{~kg}^{-1}$ for millet hybrids (table 3). Public pearl millet hybrids produced and distributed by the private sector also receive a higher price than public hybrids distributed by the SSCs.

The prices quoted by the seed companies a reported in table 3 are not necessarily equal to the prices paid by farmers. In a survey of sorghum and millet growers in Maharashtra and Gujarat we found that farmers were paying on average $R s$ $24 \mathrm{~kg}^{-1}$ for seed of private sorghum hybrids and Rs $14 \mathrm{~kg}^{-1}$ for seed of public sorghum hybrids. In the same survey farmers reported paying Rs 28 $\mathrm{kg}^{-1}$. private millet hybrids and $\mathrm{Rs} 12 \mathrm{~kg}^{-1}$ for public millet hybrids. Only farmers who ordered hybrid pearl millet seed in advance paid about the price quoted by the seed companies. The price for seed not ordered in advance tends to be the higher the closer it is to planting season.

The distribution of benefits from private breeding is estimated in table 4 assuming the absence of price effects of increased production so that con-

Table 4

Distribution of benefits from private R\&D 1987/88

Sorghum

(1)

Alternative assumptions "
\& Yield change due to hybrids
Retail price of private hybrid sced (Rs kg ${ }^{-1}$ )
Benefits
Benefits farmers/consumers " (Rs millions)
$\$$ Benefits total
Seed company net retums " (Rs millions)
$\$$ Benefits total
Distributors/dealers returns " (Rs millions)
$\$$ Benefits total

10
14.7
48.9
86
7.9
14
0.4
1

(2)

\footnotetext{
Assumptions are: Base yields $1000 \mathrm{~kg} \mathrm{ha}^{-1}$ pearl millet and $1500 \mathrm{~kg} \mathrm{ha}^{-1}$ for sorghum which are AICPMIP and AICSIP coordinators estimates for average yields of hybrids on farmers' fields. Seed rate $8 \mathrm{~kg} \mathrm{ha}^{-1}$ sorghum and $4 \mathrm{~kg}$ ha ${ }^{-1}$ pearl millet. Price of grain $1.5 \mathrm{Rs} \mathrm{kg}^{-1}$ sorghum and $1.4 \mathrm{Rs} \mathrm{kg}^{-1}$ pearl millet

- Benefits 10 farmers and consumers - (value of increased yield - seed cost) - acreage under private hybrids.

'Seed company net returas - seed company's margin from private sales - margins from public sales in table 30 sales.

Distributors/dealens - Distributors/dealers marins from privite sales-marins from public sales in table 3 * sales.
} 
sumers could not benefit from reduced commodity prices. With a 10 percent yield increase for sorghum and pearl millet, seed companies capture little more than one-sixth of the total economic gains, between 1 and 24 percent accrues to dealers and distributors and farmers receive between 61 and 86 percent of the total benefits. If we assume a 25 percent increase in millet yield, like the yield increase of MBH 110 over BJ 104, seed companies then only capture 6 percent of the benefits, dealers and distributors at most 9 percent, and farmers and consumers 85 to 94 percent. If farmers paid 1. average farm prices of Rs $28 \mathrm{~kg}^{-1}$ for private millet hybrids and Rs $24 \mathrm{~kg}^{-1}$ for seed of private sorghum hybrids instead of the prices quoted by the seed companies, farmers would still receive between 61 percent and 85 percent of the total benefits.

The benefits to farmers-are reduced and sensitive to the price elasticities of supply and demand when price effects and the markets for sorghum and millet are taken into account. Using a supply elasticity of 0.4 percent [1] and demand elasticity of -1.5 [4], farmers gain 75 percent of the benefits and consumers 25 percent [7]. If a lower demand elasticity of -0.6 is used, farmers still gain 58 percent of the benefits.

\section{Implications for policy}

The evidence reported above suggests that private research is a socially beneficial activity which ought to be encouraged by agricultural re. search policy. Policy measures are unlikely to have desired effects unless they are selected with an 8 eciation of the major factors affecting private rourch. Research reported in [3] indicates that three factors influence $R \& D$ investment by companies: (i) expected price of new products or of products produced by new processes in competitive industries or expected demand for these products in an oligopolistic industry; (ii) appropriability of returns to R\&D either through property rights to research products or, in the absence of such rights, through a competitive advantage derived from the technical characteristies of the research products, and (iii) technological opportunity or likely productivity of R\&D in producing new products or processes.
In India, government policies affect all three factors. First, government influences seed prices directly or indirectly through the pricing and supply policies implemented. by the NSC and SSCs. Second, government affects seed companies' ability to appropriate the benefits from research through the rules and laws governing land ownership and intellectual property rights. Finally, public seed research provides germplasm and irained personnel to research departments of private firms opening new technological opportunities for perceptive private firms.

\subsection{Measures 10 encourage demand expectations}

Firms' expectations about future demand for private hybrids are in part based on past successes. For example, MAHYCO developed and began marketing millet hybrids in the late 1970 s and appeared to make handsome profits in the 1980s. Several of the major seed companies are headed by former MAHYCO employees who mentioned MAHYCO's success as a factor in their decisions to invest in research.

MAHYCO's profits were based on its ability 10 raise the price of seed. The companies we interviewed clearly felt more at liberty to set the prices for private hybrids than for hybrids developed in the public sector. Even though there is currently no explicit price control on seeds, companies are afraid that price controls would be imposed if prices charged for seed of hybrids bred in the public sector were regarded as 100 high by the government. The firms report that this was one reason why they needed to develop their own private hybrids.

The sales of a new hybrid will depend on its superiority over other private and public hybrids and varieties. Thus the success of public research programs of ICAR institutes, the SAUs and ICRISAT at producing good varieties, reduces the size of markets for private hybrids. At present most of the hybrids on the market are public hybrids, which reduces sales and the price seed companies can charge for their hybrids. However, the speed with which the sale of private hybrids is increasing (table 2) suggests that private hybrids are still profitable with the current policies of SSCs and NSC.

To the extent that the general sales of the company as opposed to the specific sales of private 
hybrids influences research, competition. from NSC, SFCI and the SSCs could be an important factor. These government institutions have a 50 percent share of the commercial seed market and strongly influence prices of wheat and rice seed. They are not as important in supplying the commercial seed of pearl millet and sorghum hybrids. The largest private companies are unimpressed by the competition from the SSCs which they say cannot supply enough seed of sufficient quality to cut into the companies' markets for hybrids. Representatives of major companies believe that farmers would continue to buy hybrid seed from private companies even if the SSCs extended their production capacity. Their confidence is founded on the higher germination rates, lower content of weed seed, and lower dirt content of their seed.

Thus the principle policy change which would make private research more profitable would be to reduce the output of public plant breeding. Reducing the size of public seed supply might also stimulate demand for private hybrids. However, the positive impact of such policies on private research would have to be weighed against the negative impact of less public sector R\&D.

\subsection{Appropriability of the returns to rescarch}

Research is usually conducted in the public sector when private rescarch institutions cannot cost-effectively exclude non-buyers from using the products of research. Exclusion of non-buyers can be achieved technically or legally. Hybrids are a technical means of exclusion because hybrids yield substantially less when seed is regrown. However, the exclusion obtained from hybrids is imperfect in India. Land ceiling laws prevent seed firms from acquiring sufficient land to grow hybrids for seed production. Being unable to integrate seed production, seed companies have to rely on contract farmers for producing hybrid seed. There are frequent reports of contract farmers who opportunistically renege on their contracts and sell hybrid seed to the highest bidder rather than the company with whom they have contracted. Modifying land ceilings for seed companies might reduce this nuisance.

Legal rights to the products from breeding research allow breeders to prevent other commercial seed producers from marketing, without license, seed bred by the holder of the rights. Examples of such laws are the Plant Variety Protection Act in the USA or national laws of most European countries which conform with the rules of the International Union for the Protection of New Varicties of Plants (UPOV). Economic research in the USA suggests that legal rights can stimulate rescarch on varieties which do not have the in-built protection of hybrids [5]. India is considering the introduction of plant variety rights, as a way of controlling this problem with contract farmers mentioned above and as a way to assist firms to appropriate some returns from breeding varictics. In the long term the effect on research intensity of such legislation would crucially depend on how effectiv such laws could be enforced through an alrea overburdened judicial system.

\subsection{Technological opportunity}

Crop breeding is justifiable if the yield potential of a crop has not yet been fully exploited or if yields are threatened by yield-reducing pests and diseases which are adapting to available cultivars. The yield potential of both sorghum and millet still provides for ample research opportunity. Moreover, downy mildew, a discase that adapts to resistant cultivars and has led to the breakdown of resistance in millet cultivars, provides a continuous challenge for millet breeders.

The ability of seed companies to realize technological opportunities depends on the availability of genetic material suitable for their breeding programs and the state of their plant breeding technology and knowledge. In India, as elsewhere, the public sector has been the most important source for advances in the knowledge and technology of plant breeding. Private breeding would be unlikely to progress without this indirect support.

In our survey we found that most compan! rely heavily on the public sector and on ICRISAT for the provision of breeding material and only a few use their own collections of germplasm (table 5). The companies that are connected with foreign companies reported use of their own collections, which undoubtedly include foreign sorghum germplasm.

Public support will continue to be particularly important for the development of hybrids resistant to downy mildew. Although 12 companies are involved in millet breeding, only a few are developing disease-resistant male-sterile lines from 
Table 5

Private companies' use of millet and sorghum breeding material from the public sector

Pearl Sorghum
millet

\begin{tabular}{lcc}
\hline Number of companies using breeding material from \\
ICRISAT & 16 & 6 \\
AICSIP/AICMIP & 6 & 3 \\
University & 6 & 3 \\
Foreign company & 0 & 2 \\
Other Indian company & 4 & 2 \\
Own collection & 7 & 5 \\
Number of companies receiving different types \\
of mnterial from ICRISAT & 8 & 6 \\
U malerial & 7 & 4 \\
inurseries & 19 & 10 \\
Breeders seed & 11 & 3 \\
Number of companies commercially producing \\
ICRISAT hybrids & 5 & 4 \\
Private hybrids & 11 \\
\hline
\end{tabular}

- GRU is the Genetic Resources Unit.

Source: Survey.

which resistant hybrid seed can be produced. The public sector will probably have to continue breeding male-sterile lines that incorporate resistance to downy mildew. How vital public genetic material is for private hybrid breeding, is illustrated by company representatives who pointed out in personal interviews that all of the new millet hybrids and two of the sorghum hybrids descended from genetic material provided by ICRISAT.

\subsection{Regulations on market entry}

Government policy probably limited private breeding research expenditure through restrictions 1 prevented the largest Indian companies and forugn-owned companies from entering the seed industry. Soon after these restrictions were lifted in 1987, a number of large firms entered the industry. Most of them have established R\&D facilities for plant breeding or extended research programs that they have in other industries.

\section{Summary and conclusions}

Defying widespread belief that small-farmer subsistence agriculture in developing countries cannot sustain a commercial private breeding in- dustry for food crops, a vigorous private breeding industry for sorghum and millet has developed in India. Evidence provided by 24 leading private breeding enterprises in a questionnaire survey and personal interviews indicates that private investment in breeding research in these crops is comparable with the investment by public national research institutions. Although prices for seed of cultivars bred in the private sector are substantially higher than prices for cultivars bred in the public sector, most of the benefits from private breeding research accrue to farmers and consumers.

Given the capacity of the private sector 10 contribute substantially to total national breeding research capacity, some policy adjustment should be considered. Although policies aimed at strengthening private companies' ability to appropriate the returns to research through legal property rights to new plant material would be desirable, their effect on private research intensity is likely to be limited. More feasible and effective is a public research policy that would de-empha. size public breeding of commercial hybrids which compete with private hybrids and concentrate instead on more basic aspects of breeding that are not or can not be addressed by private firms, on providing germplasm useful for breeding hybrids, and on the breeding of varieties. Finally, public sector $R \& D$ will be most effective if private research is not regarded as a competitor to be met with suspicion but as a partner whose research efforts are worthy of recognition and support.

\section{References}

[1] J.R. Behrman and K.N. Murty, Market Impacts of Technological Change for Sorghum in Indian Near-Subsistence Agriculture, American Journal of Agriculiural Economics 67 (1985) 539-49.

[2] W. Butler and B.W. Marion, The Impact of Patent Proter tion on the U.S. Seed Indwerty and Public Plant Breeding. N.C. Project 117, Monograph 16 (University of Wisconsin. Madison, 1985).

[3] Z. Griliches, R\&D. Patents and Productivity (University of Chicago Press, Chicago, IL, 1984).

[4] K.N. Murty, Consumption and Nutritional Patterns of ICRISAT Mandate Crops in India, Progress Report No. 53 (ICRISAT Economics Proeram, Palancheru, 1983).

(5) R.K. Perrin, K.A. Hunnings and L.A. Ihnen, Some Effects of the U.S. Plant Variety Protection ACt of 1970. Economics Research Report No. 46 (Depl. of Economics and Business, N.C. State University, Raleigh, NC. 1983). 
16) W.L Peterson, A Note on the Social Returns to Private Research and Development, American Journol of Agriculpunel Ecomomices 58 (1976) 324-6.

(7) S. Ribeira. Privale Research, Social Benerits and Public Policy: The Case of Hybrid Sorchum and Pearl Millet in the Indian Seed Indusiry. MS Thesis, Rutgers University, New Brunswick (1989).
[8] S. Ribeira, Farm-level Impact of the Privale Sced Industn' in India (Department of Agricultural Economics, Rutgers University. New Brunswick, NJ, 1990).

(9) World Bank, National Seeds Project Appraisal Report (World Bank, Washington, 1976). 